\title{
ENTRE O ACONCHEGO E OS DETALHES DO COTIDIANO: A RELAÇÃO PAIS E FILHOS ADULTOS
}

Célia Regina Henriques

O objetivo desta tese é investigar a relação entre pais e filhos adultos coabitantes, na esfera doméstica familiar. Para tal empreendimento, elaboramos uma rede teórica interdisciplinar, que integrou conhecimentos provenientes do campo das terapias familiares, da sociologia, da antropologia e da psicanálise de Donald Winnicott. Pesquisamos esse universo através de um estudo de campo, realizando entrevistas semiestruturadas com 7 mães, 1 pai, 4 filhos e 4 filhas. Das análises dos discursos desses sujeitos quatro temas emergiram: os ajustes cotidianos na convivência, o jogo interativo, duas lógicas em ação e o sentido de ser família. Constatamos que nessa dinâmica interativa, vivida na vida cotidiana da família, um jogo relacional é estabelecido. A partir de pequenas negociações pais e filhos instituem os limites entre os espaços pessoais e os coletivos na relação. Nessa medida, estabelecem um contexto propício para um interjogo que transforma o espaço familiar em um espaço que faz sentido e gera reconstruções de significados.

\section{BANCA:}

Terezinha Féres-Carneiro (Orientadora)

Andrea Seixas Magalhães

Bernardo Jablonski

Maria Lucia Rocha-Coutinho

Teresa Cristina Othenio Cordeiro Carreteiro

Data da defesa: 06/03/2009 